\title{
Nutrient Uptake Vis a Vis Grain Yield of Foxtail Millet Varieties as Influenced by Nitrogen Levels in Rice Fallows
}

\author{
K. Ramyasri*, A.V. Ramana, A. Upendra Rao and P. Guru Murthy \\ Department of Agronomy, Agricultural College, Naira 532 185, Srikakulam, \\ Andhra Pradesh, India \\ *Corresponding author
}

\section{A B S T R A C T}

\section{Keywords \\ Foxtail millet, Nitrogen levels, $\mathrm{N}$ uptake, Varieties and yield \\ Article Info \\ Accepted: \\ 18 August 2018 Available Online: 10 September 2018}

A field experiment was carried out at Agricultural College Farm, Naira, Andhra Pradesh during rabi 2017-18 on sandy loam soils to study the nutrient uptake and grain yield of foxtail millet varieties as influenced by varied levels of nitrogen in rice fallows. The results revealed that nitrogen uptake was highest with the variety $\mathrm{SiA} 3156$ with elevated drymatter production and grain yield at $80 \mathrm{~kg} \mathrm{~N} \mathrm{ha}^{-1}$ and found significantly superior over rest of the varieties and nitrogen levels.

\section{Introduction}

Foxtail millet is a staple food for millions living in the arid and semi-arid regions of the world. It is native to China and regarded as an elite drought-tolerant crop. It is of climate resilient, short duration and low cost consumptive crop, nutritionally superior, providing protein and minerals at a cheaper cost. The major foxtail millet growing states in India are Andhra Pradesh, Karnataka and Tamil Nadu, contributing about 79 per cent of the total area.

Foxtail millet cultivation is an emerging scenario in rice-fallows under zero tillage, especially in areas having frugal water resources under rice-fallows in north coastal zone of A.P. as an alternate crop to pulses. Maximum yield potential can be achieved by growing high yielding varieties with improved tolerance to drought and response to fertilizer application. For higher productivity, there is a need for application of higher dose of fertilizers, especially nitrogen. Nitrogen is the major nutrient required by the millets for higher growth, yield attributes and yield (Prasad et al., 2014). Recent studies of Hasan et al., (2013) and Basavarajappa et al., (2003) indicated that there was a good response of foxtail millet to varied levels of nitrogen. Hence, promising foxtail millet varieties were tested for their response to nitrogen levels to evaluate their yield potentiality. 


\section{Materials and Methods}

A field experiment was conducted during rabi of 2017-18 at the Agricultural College Farm, Naira, Andhra Pradesh. The soil was sandy loam in texture with a $\mathrm{pH}$ of 7.04 and $\mathrm{EC}$ of $0.078 \mathrm{dS} \mathrm{m}^{-1}$, low in organic carbon $(0.61 \%)$, available nitrogen $\left(252.5 \mathrm{~kg} \mathrm{ha}^{-1}\right)$, medium in available phosphorus (29.5 $\left.\mathrm{kg} \mathrm{ha}^{-1}\right)$ and potassium $\left(352.5 \mathrm{~kg} \mathrm{ha}^{-1}\right)$. Sowing was done on $12^{\text {th }}$ December 2017 , by adopting a seed rate of $6.25 \mathrm{~kg} \mathrm{ha}^{-1}$. The seed was broadcasted uniformly to obtain optimum planting density. The plot size adopted was $6 \mathrm{~m} \times 5 \mathrm{~m}$. The experiment was laid out in RBD with factorial concept, comprising of three varieties SiA3085 $\left(\mathrm{V}_{1}\right), \operatorname{SiA}-3156\left(\mathrm{~V}_{2}\right)$ and $\mathrm{SiA}-3088\left(\mathrm{~V}_{3}\right)$ and four nitrogen levels viz., control $\left(\mathrm{N}_{1}\right), 40$ $\mathrm{kg} \mathrm{N} \mathrm{ha}^{-1}\left(\mathrm{~N}_{2}\right), 60 \mathrm{~kg} \mathrm{~N}^{-1}\left(\mathrm{~N}_{3}\right)$ and $80 \mathrm{~kg} \mathrm{~N}$ $\mathrm{ha}^{-1}\left(\mathrm{~N}_{4}\right)$ and each treatment replicated thrice. Data on growth and yield parameters parameters like dry matter accumulation at maturity, panicle length and number of filled grains panicle ${ }^{-1}$, grain yield, stover yield and nitrogen uptake was recorded. Statistical analysis of all the data are carried out following the analysis of variance technique for RBD with factorial concept as outlined by Panse and Sukhatame, 1985.

\section{Results and Discussion}

\section{Nitrogen Uptake}

\section{Effect of varieties on $\mathbf{N}$ uptake}

The nitrogen uptake by grain $\left(21.7 \mathrm{~kg} \mathrm{ha}^{-1}\right)$ was highest with the variety $\mathrm{SiA} 3156\left(\mathrm{~V}_{2}\right)$ while it was minimum with $\mathrm{SiA} 3088\left(\mathrm{~V}_{3}\right)$ which was however comparable with $\mathrm{SiA}$ $3085\left(\mathrm{~V}_{1}\right)$. Maximum uptake of nitrogen by stover $\left(21.9 \mathrm{~kg} \mathrm{ha}^{-1}\right)$ with $\mathrm{SiA} 3156\left(\mathrm{~V}_{2}\right)$ which was however, comparable with $\mathrm{SiA}$ $3088\left(\mathrm{~V}_{3}\right)$. Significantly lower nitrogen uptake was observed with $\mathrm{SiA} 3085\left(\mathrm{~V}_{1}\right)$ which was however, comparable with $\mathrm{SiA} 3088\left(\mathrm{~V}_{3}\right)$ (Table 1).

Table.1 Uptake of nitrogen $\left(\mathrm{kg} \mathrm{ha}^{-1}\right)$ by foxtail millet as influenced by varieties and nitrogen levels

\begin{tabular}{|c|c|c|c|c|}
\hline TREATMENTS & $\begin{array}{l}\text { N uptake by } \\
\text { grain }\left(\mathrm{kg} \mathrm{ha}^{-1}\right)\end{array}$ & $\begin{array}{l}\text { N uptake by } \\
\text { stover }\left(k^{\prime} \text { ha }^{-1}\right)\end{array}$ & $\begin{array}{c}\text { Grain yield (kg } \\
\text { ha }^{-1} \text { ) }\end{array}$ & $\begin{array}{l}\text { Stover yield } \\
\qquad\left(\mathrm{kg} \mathrm{ha}^{-1}\right)\end{array}$ \\
\hline \multicolumn{5}{|l|}{ Varieties } \\
\hline$V_{1}:$ SiA - 3085 & 19.0 & 19.4 & 1143 & 2151 \\
\hline$V_{2}:$ SiA - 3156 & 21.7 & 21.9 & 1290 & 2427 \\
\hline$V_{3}:$ SiA - 3088 & 18.9 & 20.4 & 1165 & 2246 \\
\hline SEm \pm & 0.51 & 0.67 & 31.59 & 72.40 \\
\hline $\mathrm{CD}(\mathrm{P}=0.05)$ & 1.5 & 1.9 & 92 & 212 \\
\hline \multicolumn{5}{|c|}{ Nitrogen Levels $\left(\mathrm{kg} \mathrm{ha}^{-1}\right)$} \\
\hline $\mathbf{N}_{1}: 0$ & 8.7 & 10.7 & 586 & 1259 \\
\hline $\mathbf{N}_{2}: 40$ & 17.4 & 18.3 & 1085 & 2074 \\
\hline$N_{3}: 60$ & 24.3 & 24.4 & 1442 & 2666 \\
\hline $\mathbf{N}_{4}: 80$ & 29.0 & 28.8 & 1684 & 3101 \\
\hline SEm \pm & 0.59 & 0.77 & 36.48 & 83.60 \\
\hline $\mathrm{CD}(\mathrm{P}=0.05)$ & 1.7 & 2.2 & 107 & 245 \\
\hline \multicolumn{5}{|l|}{ Interaction } \\
\hline SEm \pm & 1.03 & 1.35 & 63.19 & 144 \\
\hline $\mathrm{CD}(\mathrm{P}=0.05)$ & NS & NS & NS & NS \\
\hline CV\% & 8.2 & 9.9 & 8.2 & 10.4 \\
\hline
\end{tabular}




\section{Effect of nitrogen levels on $\mathrm{N}$ uptake}

Increments of added nitrogen had a distinct effect on the $\mathrm{N}$ uptake by foxtail millet. Highest uptake of nitrogen by grain and stover was observed with the application of $80 \mathrm{~kg} \mathrm{~N} \mathrm{ha}^{-1}$, which was significantly superior over $60,40 \mathrm{~kg} \mathrm{~N} \mathrm{ha}{ }^{-1}$ and no nitrogen application.

The increase in drymatter yield together with higher nitrogen levels has lead to the higher uptake of nitrogen by plants. The present investigation confirms the documented evidence of Jyothi et al., (2016).

\section{Grain and stover yield}

SiA $3156\left(\mathrm{~V}_{2}\right)$ variety of foxtail millet recorded the highest grain $\left(1290 \mathrm{~kg} \mathrm{ha}^{-1}\right)$ and stover yield $\left(2427 \mathrm{~kg} \mathrm{ha}^{-1}\right)$ over rest of the varieties tested. While, it was minimum with SiA $3085 \quad\left(\mathrm{~V}_{1}\right)$ which was however comparable with $\mathrm{SiA} 3088\left(\mathrm{~V}_{3}\right)$.

Difference in yield (Grain and Stover) levels among the foxtail millet varieties might be attributed to their genetic potentiality to utilize and translocate photosynthates from source to sink.

Large drymatter production associated with SiA $3156\left(\mathrm{~V}_{2}\right)$ together with better yield structure observed with the same variety might have translated in to significantly higher grain and stover yield.

The highest grain and stover yield (1684 and $3101 \mathrm{~kg} \mathrm{ha}^{-1}$ ) was recorded with the $80 \mathrm{~kg} \mathrm{~N}$ $\mathrm{ha}^{-1}$ and was significantly superior over 60,40 $\mathrm{kg} \mathrm{N} \mathrm{ha}^{-1}$ and absolute control.

This might be due to increased nitrogen uptake in the grain and stover with progressive increase in the supply of nitrogen to the crop. Khan and Krishna (2016) reported that, the grain and stover yield of foxtail millet increased significantly with the subsequent increase in nitrogen levels.

On the basis of present study, it can be concluded that higher productivity and nitrogen uptake of foxtail millet could be obtained with cultivation of variety $\mathrm{SiA} 3156$ with the application of $80 \mathrm{~kg} \mathrm{~N} \mathrm{ha}^{-1}$ during rabi season of north coastal zone of Andhra Pradesh.

\section{References}

Basavarajappa, R and Basavaraj, P.K. 2003. Response of proso millet (Panicum miliaceum) to NPK fertilizers in shallow red soils. Karnataka Journal of Agricultural Sciences. 16(2): 213-215.

Hasan, M.S., Rashid, M.H., Rahman, Q.A., and Mamun, M.H. 2013. Influence of seed rates and levels of NPK fertilizers on drymatter accumulation and yield performance of foxtail millet (Setaria italica L.). Bangladesh Journal of Agricultural Research. 38(4): 689-704.

Jyothi, K.N., Sumathi, V and Sunitha, N. 2016. Productivity, nutrient balance and profitability of foxtail millet varieties as influenced by levels of nitrogen. IOSR Journal of Agriculture and Veterinary Science. 9(4): 18-22.

Panse, V.G and Sukhatme, P.V. 1978. 1985. Statistical Methods for Agricultural Workers. ICAR, New Delhi. pp. 100174.

Prasad, S.K., Singh, M.K and Singh, R. 2014. Effect of nitrogen and zinc fertilizer on pearl millet (Pennisetum glaucum) under agri-horti system of eastern Uttar Pradesh. The Bioscan. 9(1): 163-166. 


\section{How to cite this article:}

Ramyasri, K., A.V. Ramana, A. Upendra Rao and Guru Murthy, P. 2018. Nutrient Uptake Vis a Vis Grain Yield of Foxtail Millet Varieties as Influenced by Nitrogen Levels in Rice Fallows. Int.J.Curr.Microbiol.App.Sci. 7(09): 2626-2629. doi: https://doi.org/10.20546/ijcmas.2018.709.327 